\title{
The Future of Indonesia Islamic Banking Industry: Bankruptcy Analyzing the Second Wave of Global Financial Crisis
}

\author{
Patria Yunita \\ University of Indonesia, Indonesia, patria.yunita01@ui.ac.id \\ Corresponding email: patria.yunita@gmail.com
}

Received: June $7^{\text {th }}, 2020$

Revised: June $30^{\text {th }}, 2020$

Article History

Accepted: July $20^{\text {th }}, 2020$

\begin{abstract}
This study aims to analyze the resilience of the Indonesia Islamic banking industry from bankruptcy risk in times of financial crisis. This study use binary regression as dependent variable. The Islamic banking industry bankruptcy risk generated from capital buffering changes in accordance with POJK No. 11 / POJK.03 / 2016. Economic Growth, BI rate, Inflation rate and Islamic Money Market O/N rate as independent variables. To anticipate the unobserved heterogeneity, Bank Profitability, USD Exchange Rate, Federal Reserves Interest Rate and Money Supply (M2) are used as control variables. Data analysis to predict bankruptcy uses logistic regression model of the global financial crisis in Indonesia. Data obtained from monthly statistics report of Bank Indonesia and the Financial Services Authority from Januari 2008 until December 2019 by the structural break which impacted the Islamic banking capital on December 2012. Our analysis divide indonesia financial condition into two difference time, before and after the structural break. By Probit Logit Regression Model, it was concluded that USD exchange rate is independent variable which is consistently influence the probability of islamic banking bankruptcy risks in all period. $\mathrm{BI}$ rate not significantly affected the probability of Islamic banking bankruptcy because profit and loss sharing method applied in Islamic banking. Before the structural break the probability of bankruptcy significantly affected by Money Supply, USD exchange rate and economic growth. But after the structural break, the probability of bankruptcy significantly affected by Bank Profitability, USD exchange rate, BI rate and Islamic Money Market rate. This model precisely predicted by Count R Squared of $75.81 \%-86.67 \%$.

Keywords: Covid-19 Pandemic, Bankruptcy Risk, Islamic Banking Industry, Probit Logit.

JEL Classification: G01; G21; G32; G33
\end{abstract}

@ IJIEF 2020 published by Universitas Muhammadiyah Yogyakarta, Indonesia All rights reserved

DOI:

https://doi.org/10.18196/ijief.3227
Web:

https://journal.umy.ac.id/index.php/ijief/article/view/9018

Citation:

Yunita, P. (2020). The future of Indonesia Islamic banking industry: Bankruptcy analysis of second wave of financial crisis. International Journal of Islamic Economics and Finance (IJIEF), 3(2). 199-226. DOI: https://doi.org/10.18196/ijief.3227 
Yunita $\mid$ The Future of Indonesia Islamic Banking Industry: Bankruptcy Analyzing the Second Wave of Global Financial Crisis

\section{Introduction}

\subsection{Background}

Financial System Stability is a condition where the money market, capital market and banking system risks are minimized. In Indonesia, $80 \%$ of financial system is dominated by transactions in the banking sector. The turmoil in the banking sector affects the stability of the financial system. The Covid-19 pandemic that has occurred in China since November 2019 has an impact on the international financial system which in the end has given a certain impact to the banking sector and the stability of Indonesia financial system.

The researchers predict that there will be global economic stagnation and the financial crisis that hit the international financial system. Stock prices on global and national stock exchanges have experienced a sharp correction. The banking system experiences higher credit risk due to the cessation of trade and business transactions. With the condition of financial system instability, the recovery of the banking system becomes the main agenda that must be addressed by policy makers in developing countries and emerging markets. (Beek et al., 2009)

In the context of the banking system, Indonesia is undergoing a dual banking system mechanism where there is a conventional banking system and an Islamic banking system in the Indonesian banking architecture. In the covid 19 pandemic, the Financial Services Authority issued POJK regulation NO.11/POJK.03/2020 concerning the stimulus of the national economy as a countercyclical policy.

This regulation was issued in line with the development of the global spread of corona virus which has a direct and indirect impact on the performance and capacity of debtors in fulfilling credit or financing obligations, thereby increasing credit risk which has the potential to disrupt banking performance and financial system stability.

Stimulus provided in the face of higher credit risk includes an asset quality determination policy, a loan and financing restructuring policy and the provision of new funds. This regulation applies to debtors impacted by covid, debtors affected by the closure of transportation and tourism routes, debtors affected by the decline in the volume of import and export, and debtors affected by obstruction of infrastructure development projects.

Since November 2019 when the WHO annouced covid 19 pandemic, Indonesia's economic growth on a monthly basis has declined from $4.97 \%$ in November 2019 to $2.97 \%$ in February 2020. This is also in line with the 
Yunita $\mid$ The Future of Indonesia Islamic Banking Industry: Bankruptcy Analyzing the Second Wave of Global Financial Crisis

exchange rate of the rupiah against the US Dollar which weakened to the value of Rp. 14,234 per 1 USD. Based on monthly data of benchmark, interest rate the federal reserves fell by 0.25 basis points in October 2019. The policy regarding the direction of interest rates was taken in order to provide liquidity to the financial industry sector.

Similar to the policies adopted by the federal reserves, Bank Indonesia's policy towards reducing the benchmark interest rate has an impact on the performance of the Indonesian Islamic banking industry throughout the period of the spread of the pandemic. Based on The Financial Services Authority report on Islamic Banking Statistics monthly data, the Ratio of the Islamic Banking Industry throughout November 2019 to February 2020 shows a variety of fluctuations, especially a decrease in performance seen between December 2019 and January to February 2020. This is thought to be the impact of the condition of the national financial sector and the international financial sector during the pandemic in the first quarter of 2020.

The capital adequacy ratio of the Islamic banking industry was recorded at $20.48 \%$ in November 2019, down to $20.29 \%$ in January 2020. However, the non-performing financing (NPF) ratio decreased from 3.47 in November 2019 to $3.38 \%$ in February 2020. The FDR ratio decreased, which was originally in November $80.06 \%$, down to $77.02 \%$ in February 2020. This illustrates the amount of reserves held by Islamic banking in the pandemic covid-19 was greater in order to strengthen capital, so that the amount of funds disbursed to finance decreased significantly.

In terms of asset quality, the Islamic banking industry experienced a decline in November 2019 of $3.11 \%$ to $2.66 \%$ in February 2020. However, the liquidity of the Islamic banking industry increased from $29.28 \%$ to $31.17 \%$ in February 2020. This is an effort of regulators and Islamic banking industry players in mitigating the impact of the spread of the corona virus, so that Islamic banking assets have decreased between December 2019 and January to February 2020.

Between January 2008 until December 2019 before the pandemic, the financial crisis in the financial sector occurred several times. It was noted that in 2008 as a global financial crisis that had a major impact on the stability of the Indonesian financial sector. In this study we analyzed the capital resilience of the Islamic banking industry during the second wave of global financial crisis affecting Indonesia's Islamic bank in 2013 to 2017. Monthly statistic data of Islamic Banking Capital Adequacy Ratio and Return of Assets Ratio shown a fluctuations through the years. In 2008 to 2019, structural 
Yunita $\mid$ The Future of Indonesia Islamic Banking Industry: Bankruptcy Analyzing the Second Wave of Global Financial Crisis

break in financial sector have been occured, which affected the probability of bankruptcy of islamic banking.
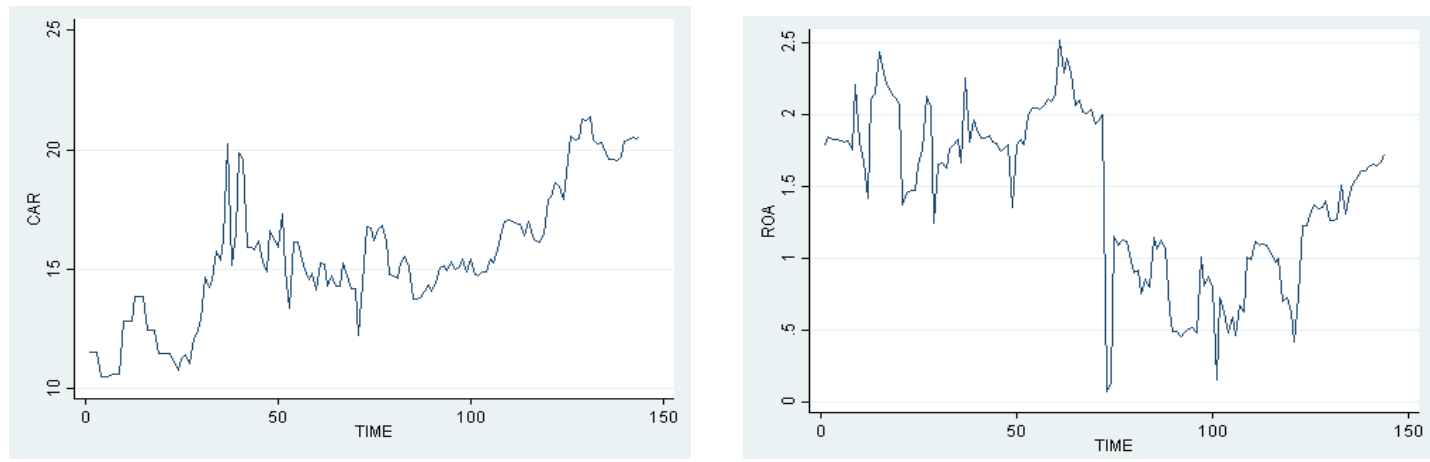

Figure 1. Level of Capital Adequacy Ratio (CAR) and Bank Proitability (ROA) Islamic Banking Industry, 2008-2019

Source: Monthly Statistic Report.

The Financial Services Authority and Bank Indonesia.(2020)

This study uses the banking system instability model of Aleksi \& Holyst (2001) to see the ability of Islamic banking in dealing with the financial crisis. By using economic variables as control variables include the Rupiah Exchange Rate against the US Dollar, Federal Reserves Interest Rates, Bank Indonesia Certificate Interest Rates, Inflation Rates, Economic Growth Rates, Money Supply (M2), Bank Profitability and Islamic Money Market O/N rate.

Indicators of the second wave of financial turmoil is the decline of Capital Adequacy Ratio of the Islamic banking industry after the first global financial crisis in 2008, which occurred on December 2012. Other analysis is to use capital buffering, which is the difference between the ratio of bank capital adequacy to the capital adequacy ratio determined by the Basel Index set out in POJK No. 11 / POJK.03 / 2016 concerning banking capital in accordance with Basel III.

Some studies predict that Islamic banking is more resilience to financial turmoil. This is a question among researchers and regulators regarding financial stability of the entire banking system. There is a difference of opinion among researchers regarding the Islamic bank's resistance in facing the financial crisis. Islamic banks should be said to be more stable in conditions of financial crisis due to the adoption of profit and loss sharing system contracts (Bourkhis and Nabi, 2013; Cihak \& Hesse, 2010). However Alqahtani \& Mayes (2018) believes that Islamic Banks have a higher risk than conventional banks.

Alqahtani \& Mayes (2018) used Market-based financial stability measures to measure the performance of Islamic banks during the 2000-2013 financial 
Yunita $\mid$ The Future of Indonesia Islamic Banking Industry: Bankruptcy Analyzing the Second Wave of Global Financial Crisis

crisis turmoil. His research took samples in 76 banks of the GCC countries. His findings say that during the Islamic crisis the bank did not have much impact on financial turmoil, but when the financial turmoil had an impact on the real sector the Islamic banks with large sizes experienced financial instability compared to conventional banks. However, Islamic banks with smaller sizes are more stable and able to withstand financial instability. Although the Islamic bank survives in a state of crisis of financial instruments that is quite high, but is affected by fluctuations that occur in the real sector.

In the Islamic economic system, especially Islamic banks there is a prohibition in Al-Quran to trade currencies as a commodity. However, allow trading that is not accompanied by interest using the profit and loss sharing system. In Islamic economics, basically there will be no inflation or turmoil in the financial system when a profit and loss sharing system is implemented. That is combined with the use of the gold standard in the monetary system. The use of the gold standard will trigger a balance in the real sector and the monetary sector.

However, the operation of the Islamic banking system in the midst of a dual banking system is dominated by conventional banking systems that still use interest rate instruments as the main variable. So that in this case Islamic banking operating in a dual banking system is affected by the financial crisis caused by changes in interest rates and other macroeconomic variables. Several studies examining the resilience of the Islamic banking system and conventional banking system amid the financial crisis have produced different conclusions.

Beck, et.al (2013) use z-scores to measure the efficiency and stability of Islamic banks, whether Islamic banks are significantly more volatile than conventional banks. The results of his study concluded that there were no differences related to liquidity risk during the Global Financial Crisis. Bourish \& Nabi (2013) use z-scores to measure Islamic banks in 16 countries, with 68 banks of which 34 are Islamic banks, the results of his analysis conclude overall, Islamic banks are more stable than conventional banks. But there is no difference between Islamic banks and conventional banks in terms of the effects of the Global Financial Crisis.

Rajhi \& Hassairi (2013) examined the stability of Islamic banks using z-scores in 16 countries, with a sample of 557 banks of which 90 were Islamic banks. The results of his research concluded that the Islamic Bank is very much more stable than conventional banks. Credit risk and income diversification are determinants of insolvency in the Islamic Bank. Kabir et.al (2015) Using accounting based and market based measures of credit risk. His research sampled 13 countries with 193 banks (37 Islamic banks). His findings conclude that Islamic banks have lower credit risk when measured using 
Yunita $\mid$ The Future of Indonesia Islamic Banking Industry: Bankruptcy Analyzing the Second Wave of Global Financial Crisis

market-based stability measures. However, it has a higher credit risk if measured by accounting based credit risk measures.

The global financial crisis has a very detrimental impact on the banking system. (Rughoo \& Sarantis, 2014). The resilience of a country's financial system is related to economic power and economic growth. Significant changes in capital, assets and liabilities of banks heighten the risk of bank instability. The researchers confirmed that in general, the two factors that caused the failure of the banking system were bad loans and the massive withdrawal of funds meant the need to maintain liquidity during the financial crisis. The very fast withdrawal rate of deposit funds heightens the risk of instability as a result of insolvency experienced by banks. On one hand, instability in the banking system has a domino effect where instability in one bank impacts the risk of other bank instability.

Previous studies used the z-score method to measure the level of instability of Islamic banking and the predictions using Probit Logit Regression. Alqahtani \& Mayes (2018) Kabir et.al (2015), Beck et.al (2013), Bourish and Nabi (2013), Rajhi \& Hassairi (2013). In this research, capital buffering ratio is used as an indicator of instability which affecting the islamic banking bankruptcy level. The capital adequacy ratio of Islamic banking has decreased and impacted the ability of banks in mitigating a systemic risks. Higher credit risk during the financial crisis and the Covid-19 pandemic turn triggered instability and the risk of possible bankruptcy.

\subsection{Research Objective}

The objectives in this study are two folds. First, analyzing the Islamic banking industry capital resilience during the second wave of financial crisis, and second, predicting the Islamic banking industry capital resilience during the covid 19 pandemic period.

The remaining organization of the paper will discuss literature review related to theory and past studies related to the topic in chapter two, followed by methodology in chapter three discussing methodology, including the data, proposed bankruptcy model and logistic regression method used. Chapter four will discuss results and analysis, followed by chapter five discussing conclusion of the study and recommendations for various stakeholders. 
Yunita $\mid$ The Future of Indonesia Islamic Banking Industry: Bankruptcy Analyzing the Second Wave of Global Financial Crisis

\section{Literature Review}

\subsection{Banking System Bankruptcy Model}

Bankruptcy can be interpreted as the inability of an entity to generate revenue and cover operational costs or it can be said as negative economic value. Bankruptcy in a corporate entity can be caused by financial distress. (Vives, 2019) The Bankruptcy Bargain Theory theory of bankruptcy was introduced by Jackson (1982) then developed by Jackson and Scott (1989). In this theory, bankruptcy is more emphasized due to failure from the aspect of credit. So in this theory it is said that creditors and debtors can rationally negotiate and determine agreements. Both parties can determine positions and strategies to reduce costs and maximize profits. One weakness of this theory is the inability to distribute wealth evenly due to the lack of collaboration or collaboration. This theory is criticized by Warren (1993) because bankruptcy assessments are considered unrealistic. From another perspective, Risk Sharing Theory emerged.

Risk Sharing Theory is a bankruptcy theory developed from Creditors Bargain Theory. Miles (2011) developed this theory by including risk variables that caused bankruptcy, that is, risks originating from exogenous variables that cannot be controlled by management. These risks are related to the risk of a decline in economic capacity due to the global recession (economic wide global downturn), industry-specific problems and government policies. Another risk originating from within a company entity is endogenous risk caused by mismanagement in governance. Another theory that talks about bankruptcy is Value Based Theory which was introduced by Korobkin (1991) explains that bankruptcy is a system that is associated with broad aspects and variations in the magnitude of risk. Korobkin believes that bankruptcy is an effect of financial distress. This issue is related to multidimensional, social political and moral aspects.

There are various kinds of bankruptcy theories that develop by including risk and financial pressure variables and their ability to pragmatically predict bankruptcy. Predictions about the bankruptcy of an entity to be interesting to study. Beaver (1966) predicts the bankruptcy of an entity by using the $t$ test on several accounting ratios. In 1968, Altman developed an analysis of multiple discriminant samples by using z-scores to predict bankruptcy. Another bankruptcy prediction model is carried out by Ohlson (1980) using the Logit regression model whereas, Back and Hensher (1973) use the Probit regression model in predicting the onset of bankruptcy of an entity. 
Yunita $\mid$ The Future of Indonesia Islamic Banking Industry: Bankruptcy Analyzing the Second Wave of Global Financial Crisis

Other more complex prediction models formulate factors related to the probability of failure of a business entity by including network variables, prices and contingency analysis of claims. Lensberg et.al (2006) used genetic programming techniques to predict bankruptcy using 28 variables. The results of his analysis concluded that company size reduces the risk of bankruptcy if profits are positive.

Pervan et al. (2011) predicts bankruptcy by using financial ratios and published financial statements. Hauser and Booth (2011) predict bankruptcy using the maximum likelihood logistic regression estimator with robust standard predictive error results. Zhang et al. (2013) and Jackson and Wood (2013) predict bankruptcy risk with market data based models, historical accounting and stock market option valuation methodology.

The bankruptcy model of the banking system was introduced by Aleksi conditioned \& Holyst (2001). In this model, banks are represented in every corner. Directional connections that are randomly distributed between banks simulate the flow of money. Where the flow of money in banks comes from assets and liabilities. The arrows in the corner represent liabilities or deposits with other banks. The arrows that contradict obligations or deposits in other banks describe banking assets, namely investment and bank credit / financing. So, on average the number of arrows going to the corner and the exit angle are the same. This illustrates that a withdrawal of funds or a bad credit will encourage banking instability. The failure of one bank will cause failure in other banks.

In dealing with the risk of bankruptcy, some countries have different methods of recovery due to instability that triggers bankruptcy risk. Steve \& Dinelis (2019) created a bankruptcy index table for various countries. In the table, Indonesia is included in the pro-liquidity category in overcoming bankruptcy conditions due to financial system instability with an index value $=1$. This means that the policies taken by the Central Bank tend to expand the liquidity of the financial market sector during the financial crisis.
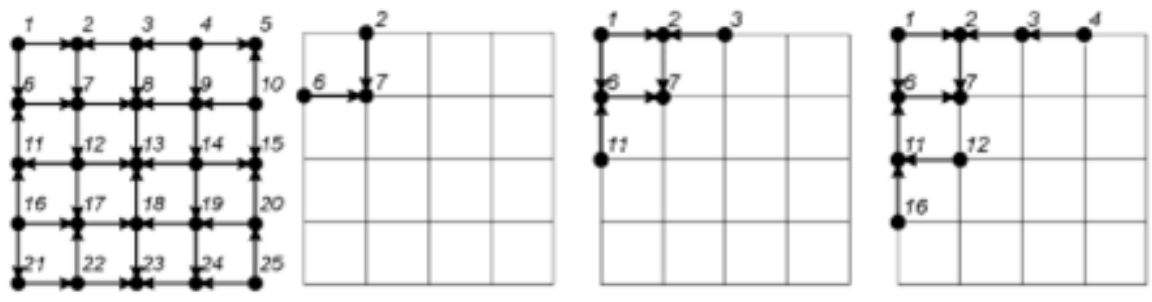

Figure 2. Mechanism of Systemic Bankruptcy Risk in the Banking System Network Source: Aleik Holyst (2001). 
Yunita $\mid$ The Future of Indonesia Islamic Banking Industry: Bankruptcy Analyzing the Second Wave of Global Financial Crisis

\subsection{Previous Studies}

Some studies predict that Islamic banking is more resistant to financial turmoil. There is a difference of opinion among researchers regarding the Islamic bank's resistance in facing the financial crisis. Islamic banks should be more stable in conditions of financial crisis due to the adoption of profit and loss sharing system contracts (Bourkhis and Nabi, 2013; Cihak \& Hesse, 2010). However Alqahtani \& Mayes (2018) believes that Islamic Banks have a higher risk than conventional banks.

Alqahtani \& Mayes (2018) analyze Financial stability of the GCC Banking Using Market-based financial stability to measure the performance of Islamic banks during the turmoil of the financial crisis in 2000-2013. The results conclude that during the crisis the Islamic bank did not have much impact on the financial turmoil, but when the financial turmoil had an impact on the real sector, the Islamic bank with a large size experienced financial instability compared to conventional banks. However, Islamic banks with smaller sizes are more stable and able to withstand financial turmoil. Although the Islamic banks hold on to funds, the condition of shocks in financial instruments is quite high, but they are affected by the turmoil in the real sector

Beck, et.al (2013) analyze 510 banks in 22 countries at 1995-2009. By using a Z-score, Islamic Bank is significantly more unstable than conventional banks. However, there is no difference in relation to liquidity risk. During the Global Financial Crisis there were no significant differences. While Bourish and Nabi (2013) analyze the stability of islamic bank in 16 countries using ZScore. The results conclude, Islamic banks are more stable than conventional banks. But there is no difference between Islamic banks and conventional banks in terms of the effects of the Global Financial Crisis.

Rajhi \& Hassairi, (2013) analyze 557 banks in 16 countries in the period of 2000-2008. The results concluded that Islamic Bank is very much more stable than conventional banks. Credit risk and income diversification are determinants of insolvency in the Islamic Bank. Kabir et.al (2015) Uses accounting based credit risk and market based measures to analyze the stability of islamic banking in 13 countries in 2000-2012. The results conclude, Islamic banks have lower credit risk if calculated using marketbased stability measures. However, it has a higher credit risk if measured by accounting based credit risk measures. During the Global Financial Crisis there were no differences in credit risk between Islamic banks and conventional banks.

Most studies about islamic banking using z-score method from Atlhman to predict bankruptcy level or to predict islamic banking instability.. The results concluded that during the financial crisis, the Islamic bank did not have much 
Yunita $\mid$ The Future of Indonesia Islamic Banking Industry: Bankruptcy Analyzing the Second Wave of Global Financial Crisis

impact on the financial turmoil, but when the financial turmoil had an impact on the real sector it was affected. In this study our analysis using capital buffering rasio to predict probability of islamic banking bankruptcy risk. Our analysis using Islamic Money Market Overnigth Rate as independent variable, which is never been used in previous studies.

\section{Methodology}

\subsection{Data}

The data used as the dependent variable is the Capital Buffering of the Islamic banking industry. Calculation of Capital Buffering refers to POJK Regulation No.11/POJK.03/2016 concerning banking capital in accordance with Basel III. In this regulation, Capital Buffering is divided into 3 types, namely capital conversation buffer, capital surcharge and countercyclical buffer. Capital conversation buffer is additional capital that functions as a buffer if there is a loss in a financial crisis period.

Tabel 1. Capital Buffering of Banking Industry

\begin{tabular}{l|l}
\hline \multicolumn{1}{c|}{ Capital Buffering Type } & \multicolumn{1}{c}{ Rate } \\
\hline 1. Capital Conversation Buffer & 2.5\% From Risk Weighted Asset \\
2. Capital Surcharge & $1-2.5 \%$ From Risk Weighted Asset \\
3. Capital Countercyclical Buffer & $0-2.5 \%$ From Risk Weighted Asset \\
\hline \multicolumn{2}{l}{ Source: POJK Regulation No.11/POJK.03/2016. The Financial Services Authority. }
\end{tabular}

According to POJK No.11 Article 3 the amount of capital conservation buffer is $2.5 \%$ of Risk Weighted Assets (RWA). The required countercyclical buffer is between $0-2.5 \%$ of the Risk Weighted Assets (RWA). Meanwhile, Capital surcharge is in the range of $1-2.5 \%$ of RWA. Capital conversation buffer for banks books III and IV, Countercyclical buffer for all banks, while Capital surcharge for banks determined has a systemic impact. So that in total in terms of bank capital resilience, the amount of Capital Buffering is 7.5\% of the capital adequacy ratio determined by Basel III. In this study the amount of Capital Buffering used was CAR - 8\%.

In this study we use Economic Growth, BI Interest rate, Inflation rate and Islamic Money Market Overnight Rate as independent variables. To anticipate unobserved heterogeinity we use USD exchange rate, Total Money Supply (M2) and The Federal Reserves Interest Rate as the control variables. Data obtained from Indonesian Economic and Financial Statistics Bank Indonesia, Indonesian Financial Stability Review Bank Indonesia, and Islamic Banking Statistic Report published by The Financial Services Authority from January 2008 until December 2019. 
Yunita $\mid$ The Future of Indonesia Islamic Banking Industry: Bankruptcy Analyzing the Second Wave of Global Financial Crisis

Table 2. Research Variables

\begin{tabular}{|c|c|c|c|}
\hline Variable & Proxy & Notation & Data source \\
\hline \multicolumn{4}{|l|}{ Dependent } \\
\hline Variable & Capital Buffering $<=7.5$. & $\mathrm{CB}$ & Bank Indonesia \\
\hline Prob $Y=1$ & Capital Buffering> 7.5 & $\mathrm{CB}$ & Statistics \\
\hline \multirow[t]{3}{*}{ Prob $Y=0$} & & & Financial \\
\hline & & & Fervices \\
\hline & & & Authority \\
\hline \multicolumn{4}{|l|}{ Independent } \\
\hline Variable & GDP & GDP & Indonesian \\
\hline Economic growth & SBI & SBI & Economic and \\
\hline SBI Interest Rates & Inf & Inf & Financial \\
\hline Inflation & IMM & IMM & Statistics, Bank \\
\hline Islamic & & & Indonesia \\
\hline \multirow[t]{2}{*}{ Market $\mathrm{O} / \mathrm{N}$ rate } & & & Indonesian \\
\hline & & & Financial \\
\hline Control Variable & USD exchange rate & USD & Stability Review, \\
\hline USD Exchange & M2 & M2 & Bank Indonesia \\
\hline Rates & The Fed & Fed & \\
\hline Money & & & Indonesian \\
\hline Supply & & & Economic and \\
\hline The Fed Interest & & & Financial \\
\hline Rate & & & Statistics, Bank \\
\hline & & & Indonesia \\
\hline & & & Indonesian \\
\hline & & & Financial \\
\hline & & & $\begin{array}{l}\text { Stability Review, } \\
\text { BI }\end{array}$ \\
\hline
\end{tabular}

\subsection{Model Development}

Our model using maximum likelihood logistic regression predictive results. The dependent variable are the probability of bankruptcy using Capital Buffering. We develop the capital buffering from CAR - 8\%. $8 \%$ is the minimum capital requirement from Basel III for banking industry. The dependent variable is binary, $Y=1$ and $Y=0 . Y=1$ is generated if Capital Buffering are less than 7.5, while $Y=0$ is generated if Capital Buffering are more than 7.5.

$y=\left\{\begin{array}{l}0 \\ 1\end{array}\right.$, where 0 did not happen bankruptcy and 1 occurred bankruptcy 
Yunita $\mid$ The Future of Indonesia Islamic Banking Industry: Bankruptcy Analyzing the Second Wave of Global Financial Crisis

The logit equation method is as follows:

$$
\begin{aligned}
& Y=\frac{e^{\beta+\beta_{1} G D P+\beta_{2} S B I+\beta_{3} I N F+\beta_{4} I M M+\beta_{5} F E D+\beta_{6} K U R S+\beta_{7} M 2+\beta_{8} R O A}}{1+e^{e^{\beta+\beta_{1} G D P+\beta_{2} S B I+\beta_{3} I N F+\beta_{4} I M M+\beta_{5} F E D+\beta_{6} K U R S+\beta_{7} M 2+\beta_{8} R O A}}}
\end{aligned}
$$

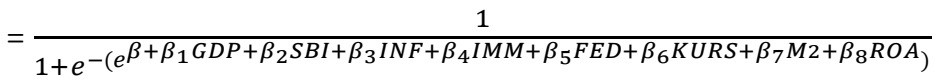

Where:

$Y \quad$ : Probability of Bankruptcy; $Y=1$, If Capital Buffering $\leq 7.5 ; Y=0$ if Capital Buffering> 7.5

GDP : Economic Growth Rate

SBI : Bank Indonesia Certificate Interest Rates

INF : Inflation rate

IMM : Islamic Money Market O/N Rate

USD : Rupiah Exchange Rate Against Dollar

FED : The Federal Reserves Interest Rate

M2 : Total Money Supply

ROA : Return on Assets

Bk $\quad$ : each coefficient is independent

Probit Model

Probit Anaysis is alternative of logit method. The main difference is that assume normal distribution of random variables (independent variables in model). The value of probability $\mathrm{P}(Y=1 \mid X)$ is the $Z$ value of a normal distribution. Higher value of $\mathrm{P}(Y=1 \mid X)$ means the event is more likely to happen. Probit regression models the probability that $Y=1$ using the cumulative standard normal distribution function, $\Phi(z)$. The Probit regression model is,

$$
\begin{aligned}
\operatorname{Pr}(Y=1 \mid X)= & \Phi\left(\beta+\beta_{1} G D P+\beta_{2} S B I+\beta_{3} I N F+\beta_{4} I M M+\beta_{5} F E D+\beta_{6} K U R S+\beta_{7} M 2\right. \\
& +\beta_{8} R O A
\end{aligned}
$$

$\Phi$ is the cumulative normal distribution function and $z=B_{0}+B_{1} X$ is the " $z$ value" or "z-index" of the model.

Marginal Effect Probit Regression

$$
Y=\Phi\left(\beta+\beta_{1} G D P+\beta_{2} S B I+\beta_{3} I N F+\beta_{4} I M M+\beta_{5} F E D+\beta_{6} K U R S+\beta_{7} M 2+\beta_{8} R O A\right),
$$

so that,

$$
\begin{aligned}
\frac{\partial Y}{\partial X_{i}}=\beta_{i} \Phi & \left(\beta+\beta_{1} G D P+\beta_{2} S B I+\beta_{3} I N F+\beta_{4} I M M+\beta_{5} F E D+\beta_{6} K U R S+\beta_{7} M 2\right. \\
& \left.+\beta_{8} R O A\right)
\end{aligned}
$$


Yunita $\mid$ The Future of Indonesia Islamic Banking Industry: Bankruptcy Analyzing the Second Wave of Global Financial Crisis

\section{3. $\quad$ Method}

Because the $Y$ compatibility must be between 0 and 1 , there is a limit. The goal of logistic regression is the same as linear regression, which is looking for a relationship of regret with the independent variable. In logistic regression do not use linear relationships. The relationship between dependent and independent variables is explained by the maximum likelihood curve where $0 \leq E\left(Y_{i} \mid X_{i}\right) \leq 1$.

\section{Logit Model}

The aim of logistic regression is similar to the linier regression is expressed dependence of magnitude $Y$ on the variable independents. Observed data are interleaved by logistic curve instead of line. (Ciski \& Kliestik, 2013).

Logistic regression Model

\section{Model Selection}

$$
Y=\frac{O d d s_{i}}{1+O d d s_{i}}
$$

Model selection between logit dan probit usually selected by cross validation or using information standards such as Akaike Information Criteria (AIC) or Bayesian Information Criterion (BIC). In this reseach we compare the prediction accuracy of models using either AIC and BIC. AIC provide an effective tool for model selection clements et.al (2015) and Dimitriou et al. (2013). The number of parameters in the model is the log likelihood function. The preferred model is the one with the minimum BIC and AIC value.

\section{Model Fit}

The estimation parameter uses the Maximum Likelihood Estimator (MLE) which describes the best distribution of the studied data. One measure of goodness of fit reported is the percent correctly predicted. (Wooldridge, 2010)

\section{LR chi2}

Prob> chi2 the probability of obtaining the chi-squates statistic given that the null hypothesis is true. Or the probability of obtaiing the chi-squares statistical if there is in fact no effect of the independent variables, taken together on the dependent variable.

\section{Pseudo $\mathrm{R}^{2}$}

Logistic regression does not have an equivalent to the $\mathrm{R}$-squared that is found in OLS regression. Pseudo R2 $=$ Model $L^{2} /-2$ LLo. -2 Llo pertains to the model with intercept only. Measures the improvement in the value of the log likelihood relative to having no X's. 
Yunita $\mid$ The Future of Indonesia Islamic Banking Industry: Bankruptcy Analyzing the Second Wave of Global Financial Crisis

\section{Count $R^{2}$}

Calculate the fraction correctly predicted $=$ fraction of $Y^{\prime} s$ for which the predicted probability is $>50 \%$ when $\mathrm{Yi}=1$ or is $<50 \%$ when $\mathrm{Yi}=0$.

\subsubsection{Structural Break Analysis}

Structural breaks can be occured in time series data or cross sectional data, when there is a sudden change in the relatioship being examined. In this study we examine structural break from islamic banking capital due to global financial crisis. In the structural break analysis it need to decide which is a more efficient then a single regression. Our analysis using the Wald test to detect the structural breaks.

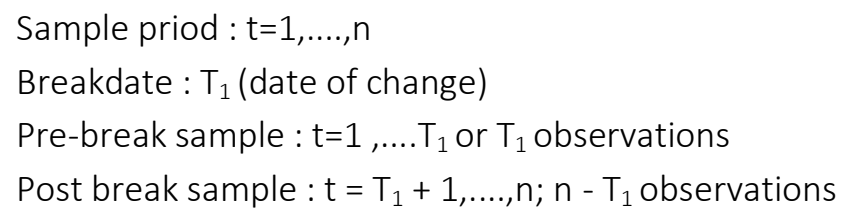

Wald Test statistic:

$$
W\left(T_{1}\right)=n\left(\beta_{1}^{\prime}-\beta_{2}\right)\left(V_{1} \frac{n}{T_{1}}+V_{2} \frac{n}{n-T_{1}}\right)^{-1}\left(\beta_{1}^{\prime}-\beta_{2}\right)
$$

Where $V_{1}$ and $V_{2}$ are standar asymototic variance estimators for $\beta_{1}$ and $\beta_{2}$ on the split sample (Hansen, 2012).

\subsection{Steps of Research}

This study strated by establishing the value of capital buffering of islamic banking industry. The probability of bankruptcy occured $(Y=1)$ generated if capital buffering is less than $7.5 \%$ while probability of no bankruptcy $(\mathrm{Y}=0)$ if capital buffering more than $7.5 \%$. To measure the global financial crisis, our analysis using structural break analysis to decribe the capital resilience of islamic banking industry as affected by the global financial condition. In accordance POJK No.11 /POJK.03/2016 concerning banking capital in accordance with Basel III. Capital conversation buffer or additional capital that functions as a buffer if there is a loss in a crisis period is $2.5 \%$ of RWA. Contercyclical buffer is $0-2.5 \%$ of RWA and Capital surcharge for D-SIB in the range of $1-2.5 \%$ of RWA. Capital conversation buffer for banks books III and IV, Contercyclical buffer for all banks while, Capital surcharge for banks determined to have a systemic impact. So that the average Capital Buffering of the Islamic banking industry in the period under this study was $7.59 \%$. 
Yunita $\mid$ The Future of Indonesia Islamic Banking Industry: Bankruptcy Analyzing the Second Wave of Global Financial Crisis

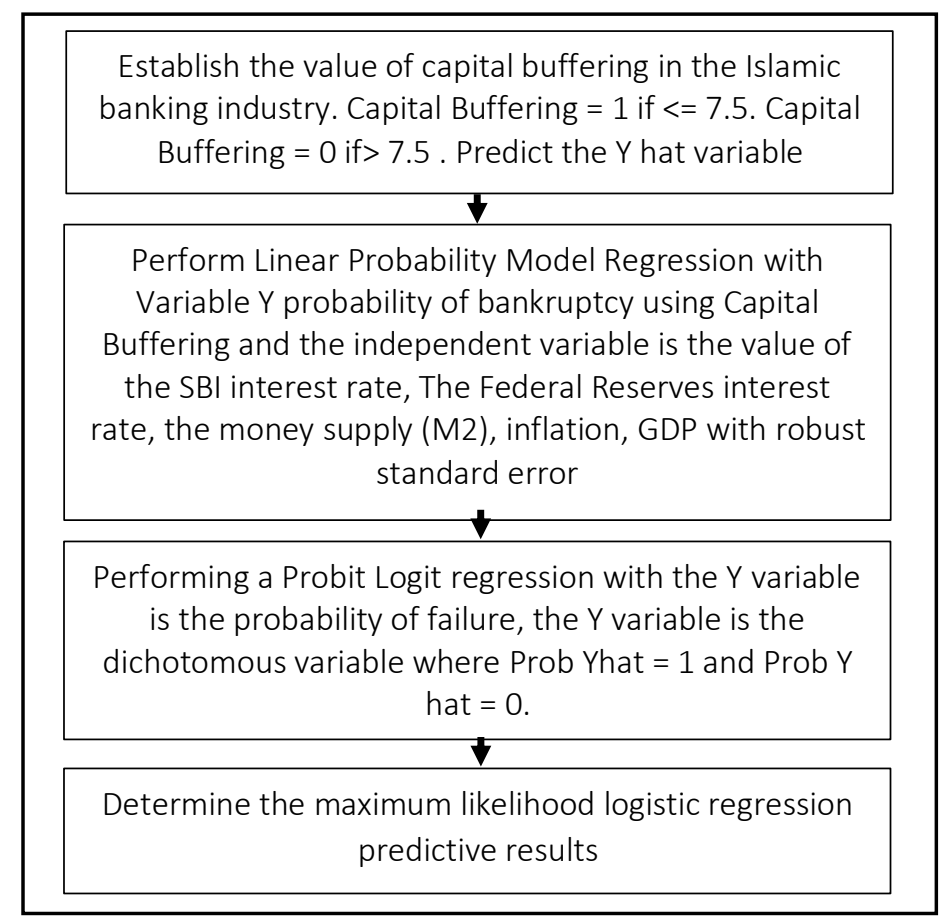

Figure 3. Research stage

To predict bankruptcy level we use the structural break of islamic banking capital resilience, we divide our analysis of probabilty of islamic banking bankruptcy level before and after December 2012. To predict $Y$ hat of binary regression our analysis using Linier Probability Model (LPM). Because of the binary regression resulting non linier of error and the probability of $Y$, so we perform Probit Logit Regression Model to determine the maximum likelihood logistic regression predictice results. 
Yunita $\mid$ The Future of Indonesia Islamic Banking Industry: Bankruptcy Analyzing the Second Wave of Global Financial Crisis

\section{Results and Discussion}

\subsection{Results}

\subsubsection{Structural Break Analysis}

On Januari 2008 until December 2019, Indonesia Financial Sector influenced by Global Financial crisis that impacted Islamic Banking profitability and capital resilience. From our analysis Bank Profitability impacted by structural break on January 2014. While, Capital resilience ratio impacted by structural break of global financial crisis on December 2012.

Capital adequacy ratio of islamic banking industry breakout on December 2012, as the impact on global financial crisis of household debt in US.
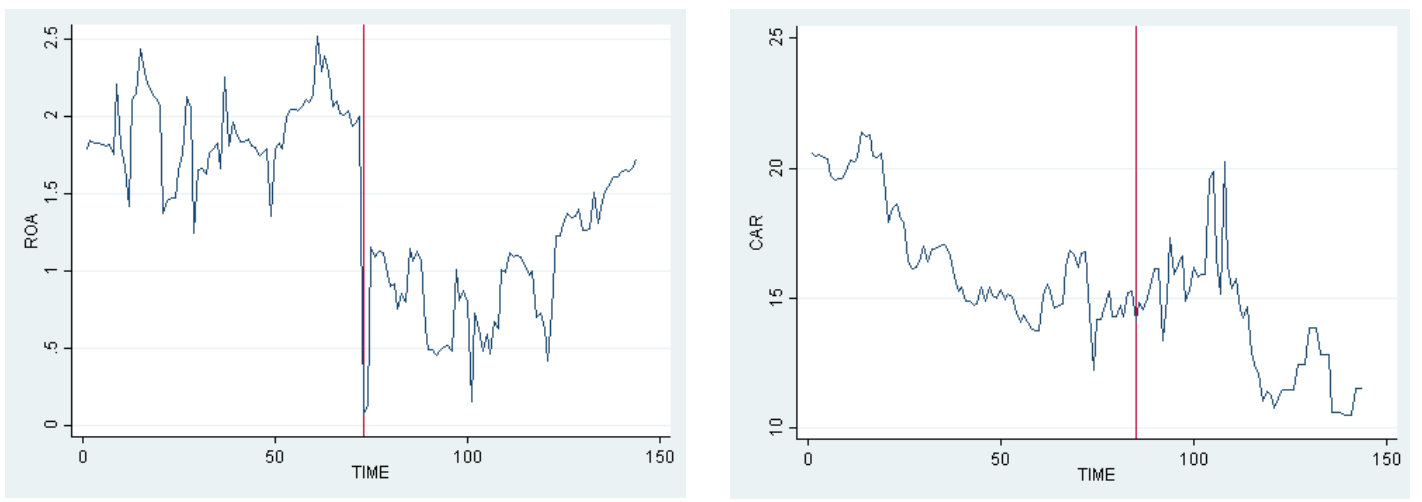

Figure 4. STATA Analysis

Structural Break of Islamic Banking Profitability and Capital Resilience January 2008 - December 2019

Table 3. Structural Break Analysis

\begin{tabular}{|c|c|c|}
\hline \multicolumn{3}{|c|}{$\begin{array}{l}\text { Test for a structural break: unknown break date } \\
\text { Number of observation : } 144\end{array}$} \\
\hline Full Sample & $1-144$ & \\
\hline Trimned Sampe & $23-123$ & \\
\hline $\begin{array}{l}\text { Estimate Break date } \\
\text { Ho: No structural break }\end{array}$ & December 2012 & \\
\hline Test & Statistic & $p$-value \\
\hline swald & 60.6700 & 0.0000 \\
\hline
\end{tabular}

Exogenous variables : Time 
Yunita $\mid$ The Future of Indonesia Islamic Banking Industry: Bankruptcy Analyzing the Second Wave of Global Financial Crisis

\subsubsection{Descriptive Statistics: Dependent Variable}

Descriptive statistics of the dependent variable, probability of bankruptcy generated from Capital Buffering and Capital Adequacy Ratio of Indonesia Islamic Banking industry are presented in table 4 and 5.

Table 4. Summary Statistics of Capital Adequacy Ratio

\begin{tabular}{ccccccccccc}
\hline \multicolumn{4}{c}{ Before Structural Break Dec 2012} \\
\hline$(1)$ & $(2)$ & $(3)$ & $(4)$ & $(5)$ & $(6)$ & $(7)$ & $(8)$ & $(9)$ & $(10)$ & $(11)$ \\
Variable & Obs & Mean & Std. Dev & Min & Max & Obs & Mean & Std. Dev & Min & Max \\
CAR & 59 & 13.85 & 2.48 & 10.51 & 20.23 & 85 & 16.64 & 2.35 & 12.23 & 21.39 \\
\hline
\end{tabular}

Table 5. Summary Statistics of Capital Buffering of Islamic Banking Industry

\begin{tabular}{ccccccccccc}
\hline \multicolumn{4}{c}{ Before Structural Break Dec 2012} & \multicolumn{5}{c}{ After Structural Break Dec 2012} \\
\hline $\begin{array}{c}(1) \\
\text { Variable }\end{array}$ & Obs & Mean & Std. Dev & Min & Max & Obs & Mean & Std. Dev & Min & Max \\
CB & 59 & 5.85 & 2.58 & 2.51 & 12.23 & 85 & 8.64 & 2.35 & 4.23 & 13.39 \\
\hline
\end{tabular}

As shown in table 4 and 5, the mean score of CAR dan Capital Buffering Islamic Banking Industry were higher after the structural break. It can be described that Indonesia Islamic banking industry manage capital buffering quiet weel in period after the structural break. The probability of islamic banking bankruptcy as shown in table 6 .

Table 6. Probability of Islamic Banking Bankruptcy Risk

\begin{tabular}{ccccccc}
\hline & \multicolumn{2}{c}{ All Period } & \multicolumn{2}{c}{ Before Structural Break } & \multicolumn{2}{c}{ After Structural Break } \\
Dec 2012
\end{tabular}

The highest probability of bankruptcy risk of islamic banking industry was before the structural break. While, after the sructural break on December 2012 islamic banking industry managed capital buffering better to kept excessive credit growth in global financial crisis. This illustrates the strength of the capital of the Islamic banking industry quite well in dealing with the potential increase in risk of the financial sector in period of December 2012 December 2019.

\subsubsection{Descriptive Statistics: Independent Variables}

In this study, the independent variables and control variables were analyzed, which are Economic Growth Rate (GDP), USD Exchange Rate, Money Supply (M2), Fed Interest Rates, SBI Interest Rate, Inflation Rate, Bank profitability and Islamic Money Market Overnight Rate. 
Yunita $\mid$ The Future of Indonesia Islamic Banking Industry: Bankruptcy Analyzing the Second Wave of Global Financial Crisis

Table 7. Descriptive Statistics of Independent Variables

\begin{tabular}{|c|c|c|c|c|c|c|c|}
\hline \multirow[b]{2}{*}{$\begin{array}{l}\text { Variable } \\
\text { (1) }\end{array}$} & \multirow[b]{2}{*}{$\begin{array}{l}\text { Obs } \\
(2)\end{array}$} & \multirow[b]{2}{*}{$\begin{array}{l}\text { Mean } \\
\text { All Years } \\
\text { (3) }\end{array}$} & \multirow[b]{2}{*}{$\begin{array}{l}\text { Std. Dev } \\
\text { (4) }\end{array}$} & \multirow[b]{2}{*}{$\begin{array}{l}\text { Min } \\
(5)\end{array}$} & \multirow[b]{2}{*}{$\begin{array}{l}\text { Max } \\
\text { (6) }\end{array}$} & \multicolumn{2}{|c|}{ Changes in mean score } \\
\hline & & & & & & $\begin{array}{c}\text { Before } \\
\text { structural } \\
\text { Break } \\
\text { (7) }\end{array}$ & $\begin{array}{l}\text { After } \\
\text { Structural } \\
\text { Break } \\
\text { (8) }\end{array}$ \\
\hline CAR & 144 & 15.50 & 2.76 & 10.51 & 21.39 & 13.85 & 16.64 \\
\hline $\mathrm{CB}$ & 144 & 7.50 & 2.76 & 2.51 & 13.39 & 5.85 & 8.64 \\
\hline GDP & 144 & 5.44 & 0.68 & 4 & 6.9 & 5.87 & 5.15 \\
\hline SBI & 144 & 6.46 & 1.22 & 4.25 & 9.5 & 6.95 & 6.11 \\
\hline INF & 144 & 5.27 & 2.34 & 2.41 & 12.14 & 6.02 & 4.75 \\
\hline IMM & 144 & 4.59 & 2.06 & 0 & 9.85 & 5.72 & 3.81 \\
\hline FED & 144 & 0.84 & 0.83 & 0.25 & 3.5 & 0.69 & 0.94 \\
\hline USD & 144 & 11484.91 & 2247.29 & 1060 & 15227 & 9352.97 & 12965 \\
\hline $\mathrm{M} 2$ & 144 & 3710205 & 1383162 & 1594390 & 6074377 & 2285719 & 4698966 \\
\hline ROA & 144 & 1.45 & 0.57 & 0.08 & 2.52 & 1.86 & 1.16 \\
\hline
\end{tabular}

From table 7 it was shown that after structural break in December 2012 until December 2019 the mean score of GDP, SBI, IMM, FED and ROA were declined. But in other side, CAR and USD exchange rate and Money Supply were increased. The fluctuation of independent variable influencing capital buffering of islamic banking industry due to the risks of global financial crisis.

\subsubsection{Analysis of Correlations}

Statistics for the correlation between variables are illustrated in table 8 . Correlation analysis between the dependent variable and the independent variable was carried out to identify the strength and the direction of relationship between the dependent variable and the independent variables. Furthermore, an analysis of correlation between independent variables was conducted to describe multicollinearity problems among the independent variables. Multicollinearity is a problem in the regression model where there is a relationship between independent variables (the correlation score in general is above 0.8 ). 
Yunita $\mid$ The Future of Indonesia Islamic Banking Industry: Bankruptcy Analyzing the Second Wave of Global Financial Crisis

Table 8. Correlations Between Dependent - independent Variables

\begin{tabular}{cccc}
\hline $\begin{array}{c}\text { Variables } \\
(1)\end{array}$ & $\begin{array}{c}\text { All Period } \\
\text { Jan 2008-Dec 2019 } \\
(2)\end{array}$ & $\begin{array}{c}\text { Before Structural Break } \\
\text { Dec 2012 } \\
(3)\end{array}$ & $\begin{array}{c}\text { After Structural Break } \\
\text { Dec 2012 } \\
(4)\end{array}$ \\
\hline Obs & 144 & 59 & 85 \\
GDP & -0.1165 & -0.4146 & -0.1612 \\
SBI & -0.5706 & -0.4780 & -0.5032 \\
INF & -0.4775 & -0.2294 & -0.6171 \\
IMM & -0.1084 & 0.0186 & 0.2513 \\
FED & 0.3169 & -0.5514 & 0.9213 \\
USD & 0.5621 & -0.0927 & 0.6188 \\
M2 & 0.7587 & 0.6945 & 0.8196 \\
ROA & -0.2146 & 0.1301 & 0.1268 \\
\hline
\end{tabular}

As shown in the table 8, it was changes of relationship between dependent and independent variables during the period of the study. Islamic Money Market O/N Rate, FED, USD and ROA are independent variables were not consistently influenced the probability of bankruptcy of islamic banking industry before and after the structural break. While GDP, SBI and Inflation were consistent.

From the data presented in table 8 it can be seen that in general there is no multicollinearity on all dependent variables and independent variables in all period (January 2008-December 2019), and before the structural break (January 2008-November 2012). Multicollinearity occured in period after structural break, December 2012 - December 2019. The independent variable of The federal reserves interest rate and money supply consist of multicollinierity and strongly correlated with dependent variables. So, our analysis dropped the two variables the FED and $M 2$ to analyze the bankruptcy risk after the structural break.

\subsubsection{Logitic Regession Model}

In predicting the capital resistance of the Islamic banking industry, the probability of bankruptcy of the Islamic banking industry during the second wave of the financial crisis was analyzed using the Linear Programing Model (LPM). The results of the Linear Programming Model (LPM) regression indicate the presence of multicollinearity and heteroscedasticity, so that a robust standard error is performed with $\alpha=5 \%$. The results of the LPM model analysis concluded that the SBI, the Fed Interest Rates, Money Supply (M2) and GDP significantly influence the risk of bankruptcy in the Indonesian 
Yunita $\mid$ The Future of Indonesia Islamic Banking Industry: Bankruptcy Analyzing the Second Wave of Global Financial Crisis

Islamic banking industry. Next predict $Y$ hat and residuals over regression. Graphical analysis shows patterned residuals where there are values of $Y$ hat $<0$ and $Y$ hat $>1$, so predictions are made using Probit Logit Regression Model.

Stratistic results of the Logistic regression model in the period January 2008December 2019, January 2008-November 2012 and December 2012December 2019 as shown in table 9.

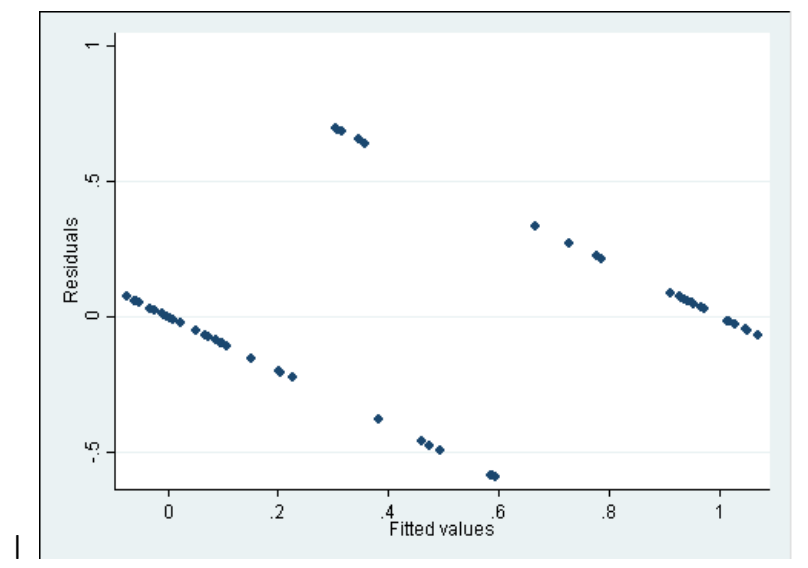

Figure 4. Residual and Y hat Linier Probability Model

Tabel 9. Probit Logit Estimates for Probability of Islamic Banking Bankruptcy Risk

\begin{tabular}{|c|c|c|c|}
\hline $\begin{array}{l}\text { Dependent variable: } \\
\text { Probability of Islamic } \\
\text { Banking Bankruptcy }\end{array}$ & $\begin{array}{c}\text { All Period } \\
\text { Jan 2008-Dec2019 }\end{array}$ & $\begin{array}{c}\text { Before } \\
\text { Structural Break } \\
\text { Jan 2008-Nov } 2012\end{array}$ & $\begin{array}{c}\text { After } \\
\text { Structural Break } \\
\text { Dec 2012-Dec } 2019\end{array}$ \\
\hline Independent Variables & Logit Model & Probit Model & Probit Model \\
\hline INF & $-0.554 * *$ & 0.03 & -0.11 \\
\hline SBI & 0.638 & -0.19 & $1.21 * * *$ \\
\hline FED & $-1.351 * * *$ & omitted & omitted \\
\hline M2 & $-562 * * *$ & $-326 *$ & omitted \\
\hline USD & $0.0019 * * *$ & $0.00068 *$ & $-0.0011 * * *$ \\
\hline GDP & $-5.3 * * *$ & $-2.31 * *$ & 0.36 \\
\hline ROA & $3.04 * * *$ & 0.77 & $-0.95 *$ \\
\hline IMM & $0.42 * *$ & -0.52 & $0.69 * *$ \\
\hline Number of Observations & 144 & 59 & 85 \\
\hline LR chi2 & LR chi2 (8) 101.54 & LR chi2 (7) 35.80 & LR chi2 (6) 69.59 \\
\hline Prob $>$ Chi2 & 0.0000 & 0.0000 & 0.0000 \\
\hline Pseudo R-squared & 0.5158 & 0.5053 & 0.5920 \\
\hline Log Likelihood value & -47.65 & -17.52 & -23.98 \\
\hline $\begin{array}{ll}\text { Percent } & \text { correctly } \\
\text { predicted } & \end{array}$ & $82.64 \%$ & $79.66 \%$ & $85.88 \%$ \\
\hline Sensitivity & $87.80 \%$ & $80.95 \%$ & $85.00 \%$ \\
\hline Specificity & $75.81 \%$ & 76.475 & $86.67 \%$ \\
\hline
\end{tabular}

Notes : $* * *, * * *$ indicate statistical significance at the $0.10,0.05,0.01$ level respectively. 
Yunita $\mid$ The Future of Indonesia Islamic Banking Industry: Bankruptcy Analyzing the Second Wave of Global Financial Crisis

\subsection{Discussion}

\subsubsection{Period Januari 2008-Desember 2019}

On January 2008 - December 2019 Probability of islamic banking Bankruptcy influenced significantly by Inflation rate, the federal reserves rate, Money Supply, USD exchange rate, Economic growth and Islamic money market rate. This model accurately predicted by count $R$ squared $82.64 \%$. in this period inflation rate, the federal reserves interest rate, Money Supply and Economic growth negatively significant affected the probability of islamic banking bankruptcy. While, bank profitability and islamic money market rate positively significant affected probability of islamic banking bankruptcy.

In this period, an improvement of inflation rate, the federal reserves interest rate, Money Supply and Economic growth decreased the probability of islamic banking bankruptcy risks. An increased of inflation rate decreased the probability of islamic banking bankruptcy because in time of inflation, the islamic banking industry thighten the liquidity by lower financing ratio and save more to capital buffering.

In a long period, SBI rate not significantly affected the probability of islamic banking bankruptcy risks. Because islamic banking industry use the sharia based liquidity instruments to manage liquidity. Profit and loss sharing method and islamic money market instruments are used in the islamic interbank money market in order to manage the islamic banking liquidity risks in the period of crisis.

\subsubsection{Periode January 2008 - November 2012}

Based on our analysis shown in table 5, the highest probability of islamic banking bankruptcy was in this period, before the structural break. From the data published by Bank Indonesia, In January 2008-July 2009 was phase of subprime mortgage crisis in the US. The recession was not felt equally around the world including in Indonesia At this period, several aggresive policies have been adopted to promote economic recovery. In Indonesia, the fallout from the crisis began in Q4 of 2008. The global financial turbulence began to bear down on the Indonesian economy. The government and Bank Indonesia took actions in fiscal policy, monetary and real sector to contain the impact of the global crisis during 2009.

Before the structural break, probability of islamic banking bankruptcy risk influenced by Money Supply, USD exchanges rate and Economic growth. At this period, money supply and economic growth negatively significant affecting capital buffering level of islamic banking industry. By significant statistic level of $95 \%$, economic growth affected the probability of islamic 
Yunita $\mid$ The Future of Indonesia Islamic Banking Industry: Bankruptcy Analyzing the Second Wave of Global Financial Crisis

banking industry. An Improvement of the economic growth decreased the probability of islamic banking bankruptcy risk due to the higher capital buffering. Economic growth indicate the higher performance of real sector. As we analyze that, islamic banking industry distributed financing through the real sector in mudharaba or musharaka contracts. Increasing economic growth affecting lower credit risk or non performing financing of islamic banking industry.

Based on IMF reported (2012) household debt soared in the years leading up to the downturn. The concurrent boom in both house prices and the stock market impacted the structural break of indonesia islamic banking industry on December 2012.

\subsubsection{Period December 2012-December 2019}

on January December 2012 - December 2019, probability of islamic banking bankruptcy level was influenced by SBI, USD, ROA and Islamic Money Market. This model predicted by count $\mathrm{R}$ squared $85.88 \%$ bankuptcy of islamic banking industry not occured due to the capital resistance of islamic banking industry. From our analysis on January 2014, the islamic banking profitability was in line with structural break. But,at this moment islamic banking capital was able to manage the financial crisis systemic risks. Indonesia islamic banking industry have manage countercyclical buffer to anticipate excessive credit growth.

\section{Conclusion and Recommendation}

\subsection{Conclusion}

There are changes of correlation between independent and dependent variable over the period of this study. USD exchange rate is independent variable which is consistently influence the probability of islamic banking bankruptcy in all period of the study. In period of january 2008 through December 2019, shown that USD exchange rate has positive coefficcient statistically significant at a 99\% level. Before the structural break the USD exchange rate positively significant at $10 \%$ level statistic. While it changes and negatively significant affected the probability of islamic banking bankruptcy after the structural break. This is in line with the action of islamic banking practioners in hedgeing USD exchanges rate in period after the structural break. 
Yunita $\mid$ The Future of Indonesia Islamic Banking Industry: Bankruptcy Analyzing the Second Wave of Global Financial Crisis

The Federal reserves interest rate was omitted before and after the structural break, but it is significant at 99\% level in all period of study (January 2008-December 2019). In January 2008-July 2009 was phase of subprime mortgage crisis in the US. The recession was not felt equally around the world including in Indonesia. At this period, several aggresive policies have been adopted to promote economic recovery. In Indonesia, the fallout from the crisis began in Q4 of 2008. The global financial turbulence began to bear down on the Indonesian economy. The government and Bank Indonesia took actions in fiscal policy, monetary and real sector to contain the impact of the global crisis during 2009.

Economic growth is independent variable which is mostly impact the probability of islamic banking bankruptcy risk, by significant statistical level 95\%. It means that islamic banking industry influenced by the economic growth and real sector. This is in line with research conducted by Alqahtani, F \& Mayes, DG (2018) by using Market-based financial stability measures to measure the performance of Islamic banks during the turmoil of the financial crisis in 2000-2013. His findings say that during the Islamic crisis the bank did not have much impact on financial turmoil, but when the financial turmoil had an impact on the real sector the Islamic banks with large sizes experienced financial instability.

As a whole, SBI rate not significantly affected the probability of islamic banking bankruptcy risks. Because islamic banking industry use the sharia based liquidity instruments to manage liquidity. Profit and loss sharing method and islamic money market instruments are used in the interbank money market in order to manage the islamic banking liquidity risk.

\subsection{Recommendations}

\subsubsection{Recommendation for Regulator}

In line with research conducted by Alqahtani, F \& Mayes, DG (2018), our study concluded that Islamic banking industry was mostly affected by real sector. Islamic banking financing by mudharaba or musharaka principles primarily distributed to real sector, so the changes of economic growth will influenced islamic banking financing performances. The decline of real sector resulting a higher potential of bad credit risk. In the other hands, SBI rate did not significantly affect the probability of islamic banking bankruptcy risk. Islamic banking capital resilience infuenced by islamic money market instrument rate return. In order to manage islamic banking capital resistance of global financial crisis, regulator needs to create a variety of islamic money market facilities according to sharia based principles and jurisdictions. 
Yunita $\mid$ The Future of Indonesia Islamic Banking Industry: Bankruptcy Analyzing the Second Wave of Global Financial Crisis

The USD exchanges rate is the independent variable which is significantly consistent affecting the probability of islamic banking bakruptcy risk before and after the structural break. The Financial Services Authority and Bank Indonesia should be very careful by the changes of exchanges rate in order to manage islamic banking industry.

\subsubsection{Recommendation for Islamic Banking Practitioners}

The capital resilience of Islamic banking industry was influenced by the USD exchanges rate before and after the structural break. In order to manage risks because of the financial crisis, islamic banking needs to be very careful of USD exchanges rate changes. Beside the exchanges rate, islamic banking practitioners should also manage financing to real sector. Economic growth will indicate the bad credit risk performance.

\subsubsection{Recommendation for Further Research}

This research using probit logit regression predictive model to analyze the probability of islamic banking bankruptcy risk in period 2008-2019. Our suggestion for the next research is to improve our model by using panel logistic regression model and analyze laten variables in logistic regression model. 
Yunita $\mid$ The Future of Indonesia Islamic Banking Industry: Bankruptcy Analyzing the Second Wave of Global Financial Crisis

\section{References}

Abedifar, P., Molyneux, P., \& Tarazi, A. (2013). Risk in Islamic banking. Rev. Finance 17 (6), 2035-2096.

Altman, E. (1968). Financial ratios, discriminant analysis and the prediction of corporate bankruptcy. Journal of Finance, 23 (4), 589-609.

Apergis, N. (2015). Competition in the banking sector: New evidence from a panel of emerging market economics and th financial crisis. Emerging Market Review. www.elsevier.com/locate/emr.

Beaver, W. H .(1966). Financial ratios predictors of failure. Journal of Accounting Research, 4 (4), 71-111.

Beck, T., Demirgüç-Kunt, A., \& Merrouche, O. (2013). Islamic vs. conventional banking: business models, efficiency and stability. J. Bank. Finance 37 (2), 433-447.

Bernstein, S., Colonnelli, E., Giround, X.,\& Iverson, B. (2019). Bankruptcy Spillovers. Journal of Financial Economics. www.elsevier.com/locate.jfec.

Bianco, A. M., \& Yohai, V. J (1996). Robust estimation in the logistic model. In: Rieder, H., editor. Robust Statistics, Data Analysis, and Computer Intensive Methods, 1734; Lecture Notes in Statistics 109. New York: Springer-Verlag.

Black, F., \& Scholes, M. (1973), The pricing of options and corporate liabilities. Journal of Political Economy, 81 (3), 637-654

Bourkhis, K., \& Nabi, M. S. (2013). Islamic and conventional banks' soundness during the 2007-2008 financial crisis. Rev. Financ. Econ. 22 (2), 6877.

Callahan, G. (2004). Economics for Real People: Introduction to Austrian School of Thought. Auburn Al .: Misses Institutes.

Calleja, P., Borm, P., \& Hendrickx, R. (2005). Multi-issue allocation situations. European Journal of Operational Research, 164 (3). 730-747.

Čihák, M., Hesse, H. (2010). Islamic banks and financial stability: an empirical analysis. J. Financ. Serv. Res. 38 (2-3), 95-113.

Cisko, Š., \& Klieštik, T. (2013). Finančný manažment podniku II. Žilina: EDIS Publisher.

Click, R. W., \& Plummer, M. G. (2005). Stock market integration in ASEAN after the Asian financial crisis. Journal of Asian Economics. 16, 5-28.

Curiel, I. J, Maschler, M., \& Tijs, S. H. (1988). Bankruptcy Games. Zeitschrift für Operations Research. 31, A143-A159. 
Yunita $\mid$ The Future of Indonesia Islamic Banking Industry: Bankruptcy Analyzing the Second Wave of Global Financial Crisis

Dimitriou, D., Kenourgios, D., \& Simos, T. (2013). Global financial crisis and emerging stock market contagion: A multivariate FIAPARCH-DCC approach. International Review of Financial Analysis 30, 46-56.

Du Jardin, P. (2018). Failure pattern-based ensembles applied to bankruptcy forecasting. Journal Decision Support System. www.elsevier.com/locate/dss.

Hauser, R. P, \& Booth, D. (2011). Predicting bankruptcy with robust logistic regression. Journal of Data Science, 9, 565-584.

Jackson, R., \& Wood, A. (2013). The performance of insolvency prediction and credit risk models in the UK: A comparative study. The British Accounting Review, 45 (3), 183-202.

Jackson, T. H. (1982). Bankruptcy non-bankruptcy entitlement and the creditors' bargain. Yale Law Journal, 91, 857.

Jackson, T. H, \& Scott, R. E (1989). On the nature of bankruptcy: An essay on bankruptcy sharing and the creditors' bargain. Virginia Law Review, 75 (155), 168

Jones, S., \& Hensher, D. (2004). Predicting firm financial distress: A mixed logit model. The Accounting Review, 79 (4), 1011-1038.

Jos'e-Manuel, J. O. (2011). An Axiomatic Justification of Mediation in Bankruptcy Problems. Center de Recerca en Economia Industrial $i$ Economia Pública Working Paper No. 18

Kabir, M. N, Worthington, A., \& Gupta, R. (2015). Comparative credit risk in Islamic and conventional banks. Pac.-Basin Finance J. 34, 327-353.

Korobkin, D. R. (1991), Rehabilitating values: A jurisprudence of bankruptcy. Columbia Law Review, 91, 717.

Lensberg, T., Eilifsen, A., \& McKee, T. (2006), Bankruptcy theory. development and classification via genetic programming. European Journal of Operational Research, 169 (2), 677-697.

Mendonca. H. F., \& Moraes, C. O. (2018). Central Bank Disclosure as a Macroprudential Tool for Financial Stability. Journal of Economic Systems. ECOSYS 674.

Miles, D. A. (2011), Risk Factors and Business Models: Understanding the Five Forces of Entrepreneurial Risk and the Causes of Business Failure. Dissertation.com: Boca Raton FLO, 1.

Ohlson, J. A (1980), Financial ratios and the probabilistic prediction of bankruptcy. Journal of Accounting Research, 18 (1), 109-131.

Onakoya, A. B., \& Olotu, A. E. (2017). Bankruptcy and Insolvency: An Exploration of Relevant Theories. International Journal of Economics and Financial. ISSN: 2146-4138. www.econjournal.com. 
Yunita $\mid$ The Future of Indonesia Islamic Banking Industry: Bankruptcy Analyzing the Second Wave of

Global Financial Crisis

Pervan, I., Pervan, M., \& Vukoja, B. (2011), Prediction of bankruptcy companies using statistical techniques - Case of Croatia. Croatian Operational Research Review, 2, 158-167.

Rajhi, W., \& Hassairi, S. A. (2013). Islamic banks and financial stability: a comparative empirical analysis between MENA and southeast Asian countries. Productivité etcapital humain dans les pays du Sud de la Méditerranée: Région et Développement no. 37. pp. 149.

Veganzones. D., \& Severin, E. (2018). An Investigation of bankruptcy prediction in imbalanced datasets. Decsup.

Vives, X. (2019). Competition and stability in modern banking: A post-crisis perspective. International Journal of Industrial Organization.www.elsevier.com/locate/ijio.

Warren, E. (1993), Bankruptcy policymaking in an imperfect world. Michigan Law Review, 92 (2), 336-356.

Yin, S., \& Xiaoni, L. (2019). A Bibliometric study on intelligent techniques of bankruptcy prediction for corporate firms. Heliyon Journal. www.cell.com/heliyon

Zhang, Y., Shuihua, W., \& Genlin, J. (2013). A rule-based model for bankruptcy prediction based on an improved genetic ant colony algorithm. Mathematical Problems in Engineering, 1-10. 
Yunita The Future of Indonesia Islamic Banking Industry: Bankruptcy Analyzing the Second Wave of Global Financial Crisis

This page is intentionally left blank

International Journal of Islamic Economics and Finance (IJIEF), 3(2), 199-226 | 226 